\title{
Revisiting Linkages between Openness, Education and Economic Growth: System GMM Approach
}

\author{
Emiko Fukase \\ The Graduate Center, the City University of New York
}

\begin{abstract}
For 106 countries over 1969-2004, this paper revisits the relationship between openness, education and economic growth using the System Generalized Method of Moment (GMM) approach. Trade and growth are usually positively correlated and capital formation appears to be an important channel through which trade brings growth. There generally exists a positive relationship between FDI inflow and economic growth for a subset of non-OECD countries. The System GMM estimator improves substantially the estimate of the impact of education on growth relative to the models which focus on within-country changes in education, adding information on cross-country variation in education levels.
\end{abstract}

- JEL Classification: F13, F21, I20, O24, O40

- Key Words: growth, system GMM, openness, trade, education, foreign direct investment

\section{Introduction}

Many cross-country studies from the 1990s find a strong positive relationship between outward orientation and economic growth (e.g. Dollar, 1992; Sachs and Warner, 1995). These studies typically regress per capita growth rate on various openness level variables. There also exist a number of studies to assess the linkages between economic growth and foreign direct investment (FDI) and their results are

\footnotetext{
*Corresponding address: Emiko Fukase: The Graduate Center, the City University of New York, 725 West 172nd Street, \#31, New York, NY 10032, U.S.A. Tel: 212-928-1095, Fax: 212-593-5115, e-mail: efukase@gc.cuny.edu.

C2010-Center for International Economics, Sejong Institution, Sejong University, All Rights Reserved.
} 
highly heterogeneous. ${ }^{1}$ Utilizing data on FDI flows from industrial countries to 69 developing countries, Borensztein, de Gregorio and Lee (1998) find that FDI contributes to economic growth only when the host country has a minimum threshold stock of human capital.

Rodriguez and Rodrik (2001) re-investigate critically the conclusion of previous cross-country studies that openness is associated with higher rates of growth. They argue that a variety of measures of openness used in these studies are proxies for other policy or institutional variables and that the earlier results that openness enhances growth are not strong. Using the various authors' actual data sets in undertaking tests of the robustness, they show that many openness variables lose their statistical significance when these other policy and institutional variables are included in the regressions, different data are used, or different weights are utilized. Rodriguez and Rodrik warn that a liberal trade policy cannot guarantee higher growth.

Some economists argue that an attempt to isolate the impact of trade on growth in empirical analyses is futile, and emphasize the importance of combining liberal trade policies with other good policies and institutional development (Baldwin, 2003; Winters, 2004). Their recommendations include sound macroeconomic and fiscal policies, corruption-free institutions and an environment that encourages physical and human capital investments. Winters (2004) points out that many of these policies and institutions respond positively to trade liberalization (e.g. through increasing incentives to develop better institutions, promoting transparency and increasing the return to investments). Among these factors, Winters suggests education as "possibly top of any a priori list (F16) as education imparts transferable skills; increases productivity which may lead to higher output; promotes health; creates social and political capital; and facilitates the absorption of new technologies.

While there is solid microeconomic evidence of a positive return of schooling on individual wages, macroeconomic studies which focus on changes in education frequently find an insignificant or even a negatively significant relationship between education and economic growth (e.g. Benhabib and Spiegel, 1994; Krueger and Lindahl, 2001; Pritchett, 2001). For instance, Pritchett (2001) calls

\footnotetext{
${ }^{1}$ In his extensive review of home- and host-country effects of FDI, Lipsey (2004) concludes that one cannot say that there are "universal effects" of FDI on growth from the studies who find positive effects in some periods or among some groups of countries and suggests that there are circumstances, periods, and countries where FDI appears to have little relation to growth (p.369).
} 
this a "micro-macro paradox of negative externalities (p.376). ${ }^{2}$ The linkages between openness, education and growth are not settled issues.

For 106 countries over the period 1969-2004, this paper revisits the relationship between openness, ${ }^{3}$ education and economic growth, using a series of panel data techniques. In particular, the paper highlights how the results obtained by the System Generalized Method of Moment (GMM) approach (Arellano and Bover, 1995; Blundell and Bond, 1998), which solves difference and level equations as a system, bring new insights relative to the previous literature. Section II reviews summary statistics on economic growth, education and openness by growth quartiles. Section III presents a series of regressions with varying specifications. When it is not possible to isolate the partial effect of openness on growth from other related policy and economic variables, e.g., when openness variables lose statistical significance with the inclusion of control variables in my regressions, potential relationships between these variables are discussed. It is also demonstrated how the System GMM estimator may improve the estimate of the impact of education relative to the models which focus on within-country changes adding information on cross-country variation in education levels. Section IV revisits the findings of Borensztein et al. (1998), using the actual dataset used in that study. Section V summarizes my conclusions.

\section{Growth, Education, and Openness - Overview}

Table 1 shows the average annual growth rates of real per-capita GDP for 106 countries by growth performance for the period 1969 to 2004 .

The first, second, third and fourth columns present the highest, high-middle, low-middle, and the lowest quartile countries classified by their average annual growth rates during the same period. The highest quartile countries include many fast-growing East-Asian and South-East Asian economies as well as other transitional economies. Among these, one sub-Saharan African country, Botswana, was the second fastest growing country during the same period. Many OECD countries belong to the high-middle growth quartile. With an exception of Papua New Guinea, the lowest growing quartile is comprised of Sub-Saharan African, Middle-Eastern, Latin American and Caribbean countries.

${ }^{2}$ Pritchett hypothesizes that in some countries education may have created "better-educated pirates" who engage in "privately remunerative but socially wasteful or counterproductive activities" (p.387).

${ }^{3}$ Openness variables are measured by the volumes of trade and FDI as shares of GDP. 
Table 1. Average Annual Real Per Capita Growth Rates for the Periods 1969-2004

\begin{tabular}{|c|c|c|c|c|c|c|c|}
\hline \multicolumn{2}{|c|}{ Highest Quartile } & \multicolumn{2}{|c|}{$\begin{array}{l}\text { High-middle } \\
\text { Quartile }\end{array}$} & \multicolumn{2}{|c|}{$\begin{array}{c}\text { Low-middle } \\
\text { Quartile }\end{array}$} & \multicolumn{2}{|c|}{ Lowest Quartile } \\
\hline Country & $\begin{array}{c}\text { Growth } \\
\text { Rate }(\%)\end{array}$ & Country & $\begin{array}{c}\text { Growth } \\
\text { Rate }(\%)\end{array}$ & Country & $\begin{array}{c}\text { Growth } \\
\text { Rate }(\%)\end{array}$ & Country & $\begin{array}{c}\text { Growth } \\
\text { Rate }(\%)\end{array}$ \\
\hline China & 7.40 & Hungary & 2.46 & Mexico & 1.64 & Bahrain $^{12}$ & 0.59 \\
\hline Botswana & 6.80 & Spain & 2.45 & Denmark & 1.60 & Argentina & 0.57 \\
\hline Korea & 5.80 & Uganda $^{4}$ & 2.29 & Nepal & 1.55 & Senegal & 0.45 \\
\hline Singapore & 5.31 & Belgium & 2.27 & Panama & 1.53 & Jamaica & 0.44 \\
\hline Malta & 5.28 & Brazil & 2.27 & Paraguay & 1.51 & Peru & 0.41 \\
\hline Cyprus $^{1}$ & 5.21 & Pakistan & 2.26 & Barbados $^{9}$ & 1.51 & $\begin{array}{c}\text { Papua New } \\
\text { Guinea }\end{array}$ & 0.41 \\
\hline Hong Kong & 4.82 & Greece & 2.23 & Tanzania $^{10}$ & 1.47 & El Salvador & 0.34 \\
\hline Thailand & 4.68 & $\begin{array}{c}\text { Syrian } \\
\text { Arab } \\
\text { Republic }\end{array}$ & 2.20 & Ecuador & 1.44 & $\operatorname{Iran}^{13}$ & 0.31 \\
\hline Mauritius $^{2}$ & 4.31 & Italy & 2.19 & Yemen $^{11}$ & 1.31 & Burundi & 0.31 \\
\hline Ireland & 4.23 & $\begin{array}{l}\text { United } \\
\text { Kingdom }\end{array}$ & 2.14 & Algeria & 1.31 & $\begin{array}{l}\text { South } \\
\text { Africa }\end{array}$ & 0.29 \\
\hline Indonesia & 4.17 & $\begin{array}{c}\text { Mozambiq } \\
\mathrm{ue}^{5}\end{array}$ & 2.10 & Uruguay & 1.30 & Bolivia & 0.27 \\
\hline Malaysia & 4.08 & Turkey & 2.10 & Cameroon & 1.29 & Ghana & 0.20 \\
\hline Lesotho & 3.94 & Jordan $^{6}$ & 2.09 & Bangladesh & 1.27 & Zimbabwe $^{14}$ & $\begin{array}{l}4 \\
4\end{array}$ \\
\hline Poland $^{3}$ & 3.47 & Israel & 2.04 & $\begin{array}{c}\text { New } \\
\text { Zealand }\end{array}$ & 1.22 & Togo & -0.05 \\
\hline Tunisia & 3.12 & $\begin{array}{l}\text { United } \\
\text { States }\end{array}$ & 2.03 & Philippines & 1.20 & $\begin{array}{l}\text { Sierra } \\
\text { Leone }\end{array}$ & -0.37 \\
\hline $\begin{array}{l}\text { Dominican } \\
\text { Republic }\end{array}$ & 3.10 & France & 2.01 & $\begin{array}{l}\text { Republic } \\
\text { of Congo }\end{array}$ & 1.19 & $\begin{array}{l}\text { Guinea- } \\
\text { Bissau }^{15}\end{array}$ & -0.42 \\
\hline Sri Lanka & 3.06 & Canada & 1.97 & Mali & 1.17 & $\begin{array}{l}\text { Venezuela, } \\
\text { RB }\end{array}$ & -0.65 \\
\hline Portugal & 3.05 & Swaziland $^{7}$ & 1.95 & Switzerland & 1.08 & $\begin{array}{c}\text { Central } \\
\text { African } \\
\text { Rep. }\end{array}$ & -1.06 \\
\hline Egypt & 3.04 & Germany $^{8}$ & 1.94 & Malawi & 0.98 & Zambia & -1.12 \\
\hline Norway & 2.95 & Costa Rica & 1.87 & Kenya & 0.94 & Haiti & -1.21 \\
\hline India & 2.89 & $\begin{array}{l}\text { Nether- } \\
\text { lands }\end{array}$ & 1.85 & Guatemala & 0.89 & Niger & -1.55 \\
\hline
\end{tabular}


Table 1. Average Annual Real Per Capita Growth Rates for the Periods 1969-2004 (Continued)

\begin{tabular}{|c|c|c|c|c|c|c|c|}
\hline \multicolumn{2}{|c|}{ Highest Quartile } & \multicolumn{2}{|c|}{$\begin{array}{l}\text { High-middle } \\
\text { Quartile }\end{array}$} & \multicolumn{2}{|c|}{$\begin{array}{l}\text { Low-middle } \\
\text { Quartile }\end{array}$} & \multicolumn{2}{|c|}{ Lowest Quartile } \\
\hline Iceland & 2.88 & Sweden & 1.84 & Guyana & 0.84 & Nicaragua & -1.63 \\
\hline Chile & 2.76 & Australia & 1.82 & Rwanda & 0.83 & Liberia & -2.80 \\
\hline Japan & 2.66 & Sudan & 1.74 & Benin & 0.81 & $\begin{array}{c}\text { United } \\
\text { Arab } \\
\text { Emirates }^{16}\end{array}$ & -3.09 \\
\hline Finland & 2.61 & $\begin{array}{l}\text { Trinidad } \\
\text { and } \\
\text { Tobago }\end{array}$ & 1.74 & Gambia & 0.72 & $\begin{array}{l}\text { Dem. Rep. } \\
\text { of Congo }\end{array}$ & -3.60 \\
\hline Austria & 2.47 & Colombia & 1.73 & Mauritania & 0.68 & Kuwait $^{17}$ & -3.83 \\
\hline & & Fiji & 1.72 & Honduras & 0.67 & & \\
\hline
\end{tabular}

Source: The World Development Indicators, the World Bank

Notes: ${ }^{1} 1976-2004 ;{ }^{2} 1981-2004 ;{ }^{3} 1991-2004 ;{ }^{4} 1983-2004 ;{ }^{5} 1981-2004 ;{ }^{6} 1976-2004 ;{ }^{7} 1971-2004 ;{ }^{8} 1972-$ 2004; ${ }^{9} 1969-2003 ;{ }^{10} 1989-2004 ;{ }^{11} 1991-2004 ;{ }^{12} 1981-2003 ;{ }^{13} 1975-2004 ;{ }^{14} 1969-2002 ;{ }^{15} 1971-$ 2004; ${ }^{16} 1974-2002 ;{ }^{17} 1963-1989$ and 1996-2003.

Table 2 demonstrates summary statistics for GDP growth rate, GDP per capita, total education years, trade, and FDI inflow as the averages over the period 1969 to 2004 by growth quartiles.

There is substantial variation in annual real GDP per capita growth rates among these four groups of countries with averages over the period of $4.0 \%, 2.0 \%, 1.1 \%$

Table 2. Summary Statistics by Growth Quartiles for the Period 1969-2004

\begin{tabular}{|c|c|c|c|c|c|c|c|c|}
\hline & \multicolumn{2}{|c|}{ Highest } & \multicolumn{2}{|c|}{ High-middle } & \multicolumn{2}{|c|}{ Low-middle } & \multicolumn{2}{|c|}{ Lowest } \\
\hline GDP Growth (\%) & $\begin{array}{l}\text { Obs. } \\
175\end{array}$ & $\begin{array}{c}\text { Mean } \\
4.0 \\
(2.6)\end{array}$ & $\begin{array}{l}\text { Obs. } \\
184\end{array}$ & $\begin{array}{c}\text { Mean } \\
2.0 \\
(2.1)\end{array}$ & $\begin{array}{l}\text { Obs. } \\
182\end{array}$ & $\begin{array}{c}\text { Mean } \\
1.1 \\
(2.4)\end{array}$ & $\begin{array}{l}\text { Obs. } \\
178\end{array}$ & $\begin{array}{c}\text { Mean } \\
-0.66 \\
(4.6)\end{array}$ \\
\hline GDP per capita $(\$)$ & 198 & $\begin{array}{c}8136.7 \\
(9606.9)\end{array}$ & 206 & $\begin{array}{c}9449.5 \\
(8592.2)\end{array}$ & 206 & $\begin{array}{c}3820.6 \\
(7371.4)\end{array}$ & 197 & $\begin{array}{c}3198.8 \\
(7418.8)\end{array}$ \\
\hline $\begin{array}{l}\text { Total Education } \\
\text { Years }^{1}\end{array}$ & 173 & $\begin{array}{c}6.1 \\
(2.2)\end{array}$ & 189 & $\begin{array}{c}6.4 \\
(3.0)\end{array}$ & 176 & $\begin{array}{c}4.5 \\
(3.0)\end{array}$ & 168 & $\begin{array}{c}3.4 \\
(1.9)\end{array}$ \\
\hline Trade $(\% \text { of GDP })^{2}$ & 175 & $\begin{array}{c}91.7 \\
(64.6)\end{array}$ & 185 & $\begin{array}{c}62.9 \\
(37.8)\end{array}$ & 179 & $\begin{array}{c}67.9 \\
(37.5)\end{array}$ & 170 & $\begin{array}{c}61.1 \\
(32.2)\end{array}$ \\
\hline $\begin{array}{l}\text { FDI Inflow } \\
\text { (\% of GDP) }\end{array}$ & 179 & $\begin{array}{c}2.3 \\
(2.9)\end{array}$ & 181 & $\begin{array}{l}1.8 \\
(2.1)\end{array}$ & 187 & $\begin{array}{l}1.6 \\
(2.4)\end{array}$ & 181 & $\begin{array}{c}1.9 \\
(3.6)\end{array}$ \\
\hline
\end{tabular}

Sources: Author's calculation based on the World Development Indicators; Barro and Lee (2000); UNCTAD.

Notes: The standard deviations are between parentheses. "'Total Education Years" reflect average schooling years for the population over age 15 (Barro and Lee, 2000). ${ }^{2}$ Trade is measured by adding imports and exports and comparing the sum to the GDP. 
and $-0.66 \%$ for the highest, high-middle, low-middle and lowest growth economies respectively. The average real GDP per capita are recorded as $\$ 8,136.7, \$ 9,449.5$, $\$ 3,820.6$, and $\$ 3,198.8$ for these same groups. GDP per capita of high-middle growth countries on average is higher than that of the highest growth economies partly because the former group includes many high-income OECD economies. Within the subgroup of fast growers (the highest and high-middle quartiles combined), lower income countries appear on average to grow faster than higher income countries implying that the economies are converging even unconditionally. Unfortunately, within the sub-group of slow growers (low-middle and lowest quartiles), the lowest growing group records the lowest average GDP per capita implying that these economies are falling further behind.

During the same period, the high-middle quartile economies record the highest schooling attainment with 6.4 total years of education which is slightly higher than that of the highest quartile countries (6.1 years). The level of education attainments of low-middle and lowest- quartile economies are clearly low relative to the upperhalf group, registering 4.5 years and 3.4 years respectively. In terms of openness variables, trade relative to GDP reaches levels of $91.7 \%, 62.9 \%, 67.9 \%$, and $61.1 \%$ for the highest, high-middle, low-middle, and lowest quartile economies respectively. FDI inflow relative to GDP accounts for $2.3 \%, 1.8 \%, 1.6 \%$ and $1.9 \%$ for the same groups of countries.

Figure 1. Time Trends of Average Years of Schooling by Four Growth Categories

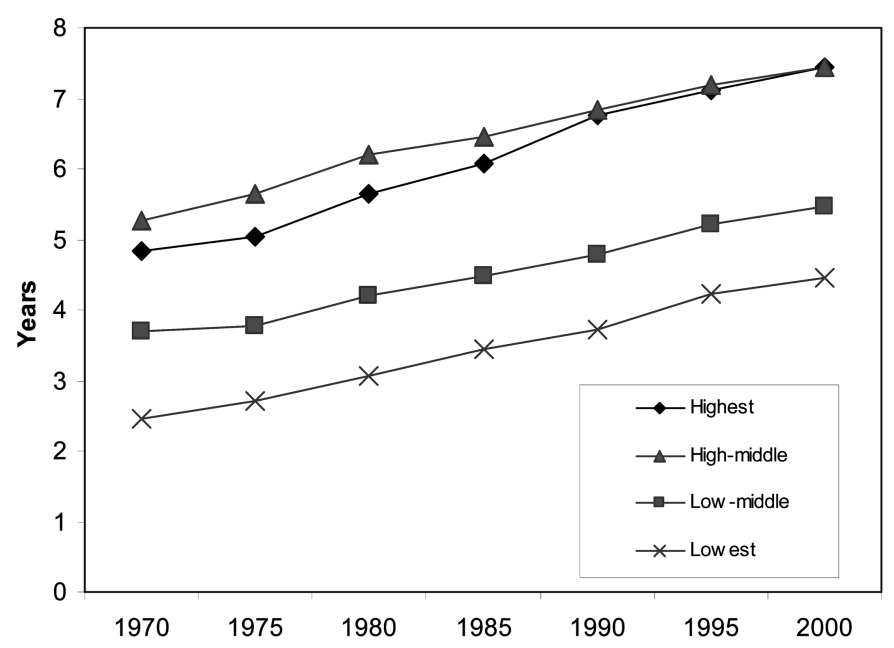

Source: Author's calculation based on Barro and Lee (2000)'s dataset.

Note: The data for 2000 are projections in Barro and Lee's dataset. 
The time trends of educational achievement by growth performance are shown in Figure 1, which plots the average years of schooling by growth category over the 1970-2000 periods.

During the past three decades, the world as a whole has achieved a substantial improvement in educational attainment as the countries in all four growth categories show steady progress. The changes in educational attainment appear to be similar across growth categories. The only noticeable exception is that the schooling years of the countries classified into the highest growth quartile rose slightly faster than the other groups converging towards the highest level attained by the high-middle quartile of countries. In contrast, Figure 1 reveals a clear positive relationship between the levels of educational attainment and economic growth. Throughout the period, the total education years for the highest and highmiddle quartile economies are higher relative to the lower groups, those attained by low-middle growing economies are lower than the upper half growing economies, and those for the lowest growing economies lag further behind. These characteristics of the actual data are consistent with the previous studies which find no or even negative association between economic growth and education growth (e.g. Benhabib and Spiegel, 1994; Pritchett, 2001). An econometric technique which exploits information on the levels of education is clearly needed to assess properly the impacts of education on growth.

\section{Regression Analyses}

\section{A. Model Specification}

In this section, I outline 5-year period growth regressions using a series of models: pooled Ordinary Least Squares (OLS), fixed effects, first-differenced GMM, and System GMM. My panel data consist of observations from 106 countries during the period 1969 to 2004 at the five year intervals. ${ }^{4}$ I first specify a growth level equation of the type considered typically in the literature (see, for instance, Caselli, Esquivel, and Lefort, Section 5, 1996):

$$
y_{i t}-y_{i(t-\hat{e})}=\beta y_{i(t-\hat{e})}+\boldsymbol{x}_{i t}^{\prime} \gamma+\xi_{t}+\eta_{i}+v_{i t}
$$

${ }^{4}$ This time frame is chosen since the period ending at the year 2004 is the latest five year interval for which the initial education data are available and the 1970s are the oldest decade when the FDI data become available for a sufficient number of countries. 
where $y_{i t}$ denotes the logarithm of real per-capita GDP in country $i$ in year $t ; \boldsymbol{x}_{i t}$ is a vector of explanatory variable; $\xi_{t}$ is the time specific effect which captures global shocks; $\eta_{i}$ is the country-specific effect; and $v_{i t}$ is the error term. The education variable is measured at the beginning of each five year period and the other variables are measured as averages from $t$ to $t-4$. Since my analysis is focused on five year growth rates, $\mathrm{l}$ is 5 in my regression. Equation (1) can be re-written as a dynamic model in the level of per capita GDP by adding $y_{i(t-1)}$ to both sides:

$$
y_{i t}=\alpha y_{i(t-l)}+\boldsymbol{x}_{i t}^{\prime} \gamma+\xi_{t}+\eta_{i}+v_{i t}
$$

where $\alpha=(1+\beta)$.

In the presence of the country specific effect $\eta_{i}$, it is well known that the OLS estimate of the coefficient on the lagged dependent variable $\alpha$ is likely to be biased upward since the lagged dependent variable is positively correlated with $\eta_{i}$ (see for instance Blundell and Bond, 1998). One approach to address the country specific effects is the fixed effects estimator. For this model, equation (1') is transformed by taking the deviation from the time series mean of each variable for each country, and then the transformed equation is estimated by OLS. In this transformation process, the country specific effects $\eta_{i}$ can be removed. A disadvantage of using the fixed effects model is that it uses only the variation within countries and the cross-sectional variation is discarded. In addition, equation ( 1 ') contains a lagged endogenous variable, namely the income term. Thus, with a small number of time series periods, the model provides biased and inconsistent estimates even if data from a large number of countries are considered. In contrast to the OLS estimate, the fixed effects estimate of the coefficient on the lagged dependent variable $\alpha$ is likely to be biased downward (Arellano and Bond, 1991).

Arellano and Bond (1991) suggest an alternative estimation technique that addresses the presence of the lagged endogenous variable and permits a certain degree of endogeneity in the other explanatory variables. Their GMM estimator first-differences Equation (1') in order to eliminate the country-specific effect, and then uses all possible lagged levels as instruments. Arellano and Bond's Difference Equation is:

$$
\Delta y_{i t}=\alpha \Delta y_{i(t-1)}+\Delta \boldsymbol{x}_{i t}^{\prime} \gamma+\Delta \xi_{t}+\Delta v_{i t}
$$


Since $\Delta y_{i\left(t-e^{\prime}\right)}$ and $\Delta v_{i t}$ are correlated, the OLS estimate of Equation (2) is inconsistent. Assuming that the error terms are serially uncorrelated in Equation (1), the level of $y_{i t}$ lagged two periods or more can be used as valid instruments for Equation (2). This is because $\Delta y_{i(t-2)}$ and earlier values are correlated with $\Delta y_{i(t-l)}$, but not with $\Delta v_{i t}$. Assuming that the $\boldsymbol{x}_{i t}$ are predetermined in the sense that $\boldsymbol{x}_{i t}$ and $v_{i t}$ are uncorrelated, but $\boldsymbol{x}_{i t}$ may be correlated with $v_{i(t-l)}$ and earlier errors, $\boldsymbol{x}_{i t}$ lagged one period or more are also used as valid instruments. Thus, the relevant moment conditions are:

$$
\begin{aligned}
& E\left[y_{i(t-s)} \Delta v_{i t}\right]=0 \text { for } s \geq 2 \imath ; t=3, \ldots . T \\
& E\left[\boldsymbol{x}_{\boldsymbol{i}(t-\mathrm{s})} \ddot{A} v_{i t}\right]=0 \text { for } s \geq \imath ; t=3 \ldots . T .
\end{aligned}
$$

Using Arellano and Bond (1991)'s first-differenced GMM estimator, Dollar and Kraay (2004) focus on the effects of within-country change in trade policy on subsequent growth. They point out that the methodology employed by the earlier literature which relates growth to cross-country differences in trade volumes is not suitable to evaluate the effects of trade policy since a significant share of the variation in trade across countries reflects countries' geographical characteristics. By taking the difference, they argue that their results are not driven by geography and other time-invariant country specific characteristics. Their first-differenced GMM estimators reveal a strong positive relationship between change in trade and growth.

Blundell and Bond (1998) point out that the first-differenced GMM estimators are likely to perform poorly when the time series are persistent and the number of time periods is small. This is because lagged levels of the series provide only weak instruments for the differenced equations. Another shortcoming of using the difference estimator is that the process of differencing to remove the country specific effect also eliminates information on the cross-country variation in levels. The System GMM estimator proposed by Arellano and Bover (1995) and Blundell and Bond (1998) combines the standard set of moment conditions in firstdifferences with lagged levels as instruments, with an additional set of moment conditions derived from the equation in levels. The availability of additional moment conditions depends on assumptions made about the correlation between $\boldsymbol{x}_{i t}$ and the country-specific effect $\eta_{i}$. Following Blundell and Bond (1998), it is assumed that the difference of $\boldsymbol{x}_{i t}$ is uncorrelated with the individual effects although $\boldsymbol{x}_{i t}$ and $\eta_{i}$ are allowed to be correlated.

Thus, the additional moment conditions for the equation in levels are: 
$E\left[\Delta y_{i(t-\imath)} u_{i t}\right]=0$ where $u_{i t}=\eta_{i}+v_{i t}$

$E\left[\Delta \boldsymbol{x}_{i t} u_{i t}\right]=0$.

Carkovic and Levine (2005) use the System GMM estimator to re-examine the relationship between FDI and growth, but find no robust evidence supporting the claim that FDI accelerates growth. Felbermayr (1995) employs the System GMM estimator to revisit the relationship between trade and growth and finds a robust and positive relationship between these variables.

\section{B. Regression Results}

Table 3 demonstrates a series of regression results using pooled OLS, fixed effects, Arellano and Bond (1991) differenced GMM, and System GMM estimators. $^{5}$

The coefficients on the lagged dependent variable in all the models are found to

Table 3. Regression Results

\begin{tabular}{lcccc}
\hline Variables & Pooled OLS & Fixed effects & Differenced GMM & System GMM \\
\hline Log of Lagged GDP & $0.98^{* * *}$ & $0.77^{* * *}$ & $0.69^{* * *}$ & $0.94^{* * *}$ \\
& $(0.013)$ & $(0.036)$ & $(0.050)$ & $(0.025)$ \\
Total Education Years & $1.85^{* *}$ & 0.30 & -3.07 & $5.49^{* * *}$ \\
& $(0.73)$ & $(1.15)$ & $(2.32)$ & $(1.41)$ \\
Inflation & $-0.0096^{* * *}$ & $-0.0069^{* * *}$ & $-0.0038^{* * *}$ & $-0.0081^{* * *}$ \\
& $(0.00080)$ & $(0.00072)$ & $(0.00080)$ & $(0.0013)$ \\
Trade as \% of GDP & 0.018 & $0.15^{* * *}$ & 0.031 & $0.13^{* * *}$ \\
& $(0.020)$ & $(0.043)$ & $(0.098)$ & $(0.043)$ \\
FDI as \% of GDP & $1.08^{* * *}$ & $1.25^{* * *}$ & $0.92^{* *}$ & 0.70 \\
m2 & $(0.38)$ & $(0.33)$ & $(0.43)$ & $(0.58)$ \\
Hansen Test & & & 0.876 & 0.930 \\
Number of Observation & 607 & 607 & 0.357 & 0.141 \\
Number of Countries & 102 & 102 & 504 & 607 \\
Number of Instruments & & & 99 & 102 \\
\hline
\end{tabular}

Notes: The dependent variable is the log of GDP. Robust standard errors are in parentheses. For the specification tests, $p$-values are reported. Time dummies are included in all the regressions (not reported).

${ }^{*}, * *$ and ${ }^{* * *}$ indicate that the coefficients are significant at the 10, 5, and 1 per cent level, respectively. Column 3 reports the results of two-step Arellano-Bond (1991) difference GMM. Column 4 shows the results of two-step Blundell and Bond (1998) system-GMM estimator with Windmeijer finite-sample correction.

${ }^{5}$ The Data Appendix provides details on data sources. 
have a value of less than one and to be statistically significant at the $1 \%$ level, providing strong evidence of conditional convergence. ${ }^{6}$

The coefficient on education ${ }^{7}$ estimated by OLS is found to be positively significant confirming the positive association between the initial level of human capital and subsequent economic growth (Barro, 1991). In contrast, using fixed effects and first-differenced GMM estimators, the coefficients on education lose statistical significance perhaps because these within country models discard information on cross-country variations in education levels. When the System GMM estimator is employed, the coefficient on education reverts to become significantly positive suggesting that the additional moment conditions derived from the level equation are highly informative.

The coefficients on trade are found to be statistically significant and positive using the fixed effects and System GMM models. The coefficients on FDI turn out to be significantly positive using all methods except the System GMM model. The coefficients on inflation show a significant and negative relationship in all the models.

The validity of instruments for first-differenced and System GMM estimator can be evaluated by a set of specification test (Arellano and Bond, 1991). The application of the Hansen test of over-identifying restrictions provides no ground to

\footnotetext{
${ }^{6}$ As expected, the magnitude of the coefficient for the lagged dependent variable estimated by OLS is higher than that estimated using the fixed effects method and it is likely that the OLS estimate and fixed effects estimates give upwards- and downwards-biased estimates respectively. The differenced GMM estimate for the lagged dependent variable is found to be below the fixed effects estimate. This downward bias in the differenced GMM estimator is consistent with the finite sample bias expected in the case of highly persistent series (Blundell and Bond, 1998). The System GMM estimator of the lagged dependent variable appears to provide the most reasonable results with the magnitude of coefficient lower than the OLS and higher than the fixed effects estimates.

${ }^{7}$ The average of male and female schooling years for the population over age 15 is used as a proxy of education. An alternative model of disaggregating education by gender was also considered. However, the latter specification reproduced somewhat "puzzling" results in the previous studies. The results of OLS model, a significantly positive coefficient on male education and a negative one on female education, are consistent with the literature (Barro and Sala-i-Martin, 1995; Wacziarg, 2001). The results of fixed effects and differenced GMM estimators reveal the reversal of the signs of male and female eduction although they are not statistically significant or are significant only marginally. These changes of signs are also consistent with the earlier works which use the first-differenced GMM estimators (Caselli et al., 1996). With the System GMM estimates, the coefficients eduction years both show positive signs although only the coefficient on female eduction is significant at the five per cent level. A potential explanation of these "unstable" results is that the collinearity between male and female schooling variables is inflating the standard errors. The Variance Inflation Factor (VIF) for female and male schooling variables are 15.7 and 13.0 respectively suggesting a high degree of collinearity between two variables. Wetherill (1986) suggests that, as a rule of thumb, a VIF higher than 10 is of concern. Thus, the specification of including separate male and female education years was dropped.
} 
reject the validity of the instruments. $\mathrm{m} 1$ and $\mathrm{m} 2$ tests show a first order serial correlation in the first- differenced equation, but detect no evidence of second order serial correlation. Overall, there are several advantages in the System GMM estimator since it controls for time-invariant country specific effects; deals with the endogeneity problem of lagged dependent variable; permits a certain degree of endogeneity in the other regressors, and optimally combines information on crosscountry variation in levels with that on within-country variation in changes.

\section{Models with Alternative Specifications}

In order to test the sensitivity of the results to the conditioning variables included, Table 4A gives the results of the models estimated by System GMM with a series of different specifications. ${ }^{8}$

The first six columns report the regression results when the openness variables are included separately. When only trade and FDI variables are included along with income terms, the coefficients on trade and FDI are positively significant at the one $\%$ level in regression (1) and in regression (2) respectively. With the latter specifications, the coefficients on the lagged dependent variable turn out to be greater than one implying that these economies would not be converging unconditionally. This result is consistent with Barro's seminal paper (1991) which finds that countries' incomes converge only when controlling for initial human capital and some other variables. The next two regressions introduce education and inflation as control variables: the coefficients of trade and FDI remain positively significant in regression (3) and in regression (4) at the one \% level. The next two regressions include gross capital formation as a control variable. As expected, the coefficients on capital are found to be highly significant at the one $\%$ level. However, adding the capital variable, the coefficients on trade and FDI lose statistical significance in regression (5) and regression (6) respectively.

The final three columns show the results when trade and FDI variables are simultaneously included in the regressions. The results of regression $(7)^{9}$ reveal that, including both openness variables, only the coefficient on trade demonstrates a statistically significant positive relationship. Controlling for government

\footnotetext{
${ }^{8}$ Although the results of System GMM models are highlighted in this paper, the outcomes of the pooled OLS and fixed effect models are reported in Appendix Table A for the purpose of comparison. ${ }^{9}$ This model is the same as that in Column 4 in Table 3.

${ }^{10}$ Assuming the trade variable to be endogenous (see footnote 6), the qualitative results are similar although the magnitudes of the coefficients of the trade variable are reduced.
} 
Table 4A. Regression Results with Alternative Specifications - Full Sample

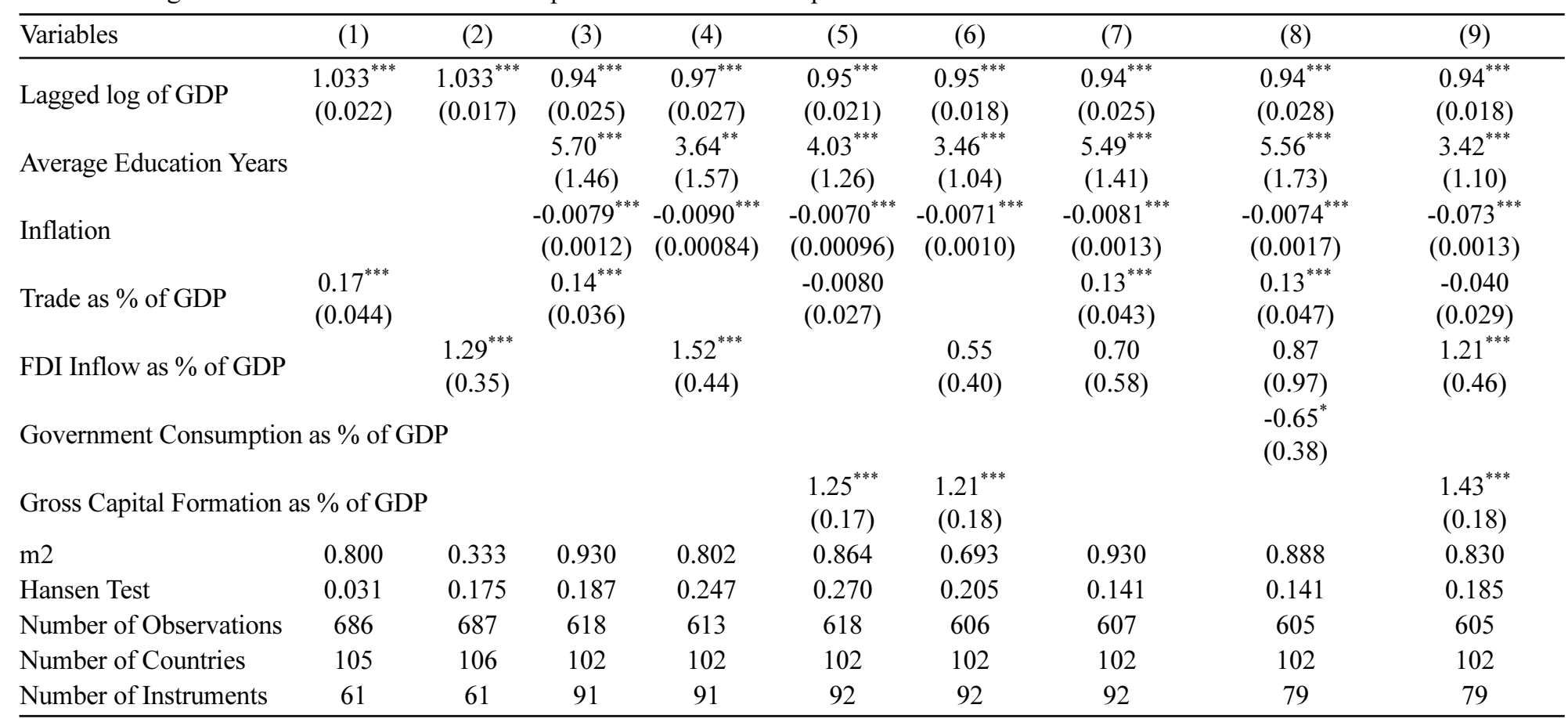

Notes: The dependent variable is the log of GDP. Robust standard errors are in parentheses. Time dummies are included in all the regressions (not reported.). ${ }^{*}$, ${ }^{* *}$ and $^{* * *}$ indicate that the coefficients are significant at the 10, 5, and 1 per cent level, respectively. All columns report two-step Blundell and Bond (1998)'s system-GMM estimator with Windmeijer finite-sample correction. For the specification tests, $p$-values are reported. In order to overcome a problem resulting from using too many instruments (Roodman, 2006), I reduced the number of instruments by dropping deeper lags as instruments if the instruments count exceeds the number of countries. Note that regression (1) fails to pass the specification test. 
Table 4B. Regression Results with Alternative Specifications - Non-OECD Countries

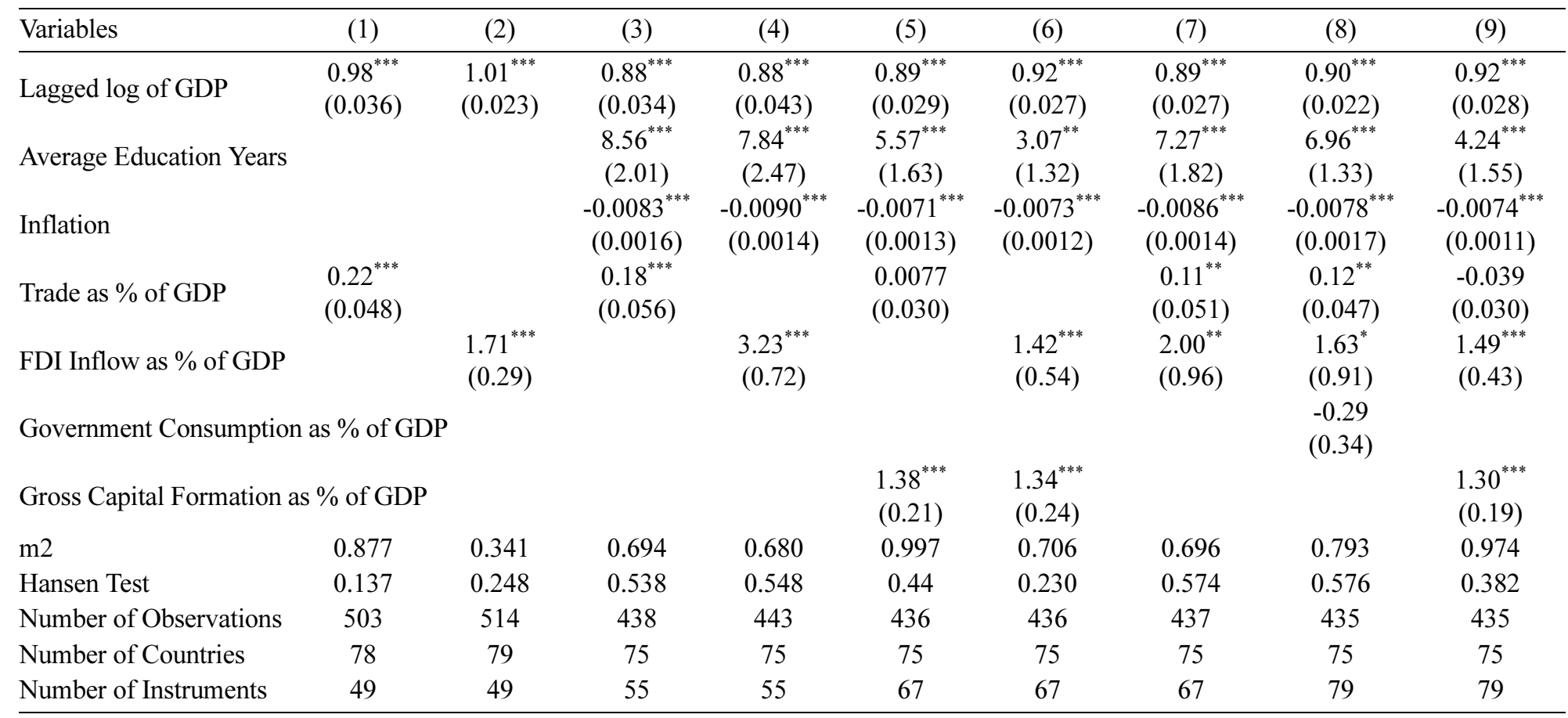

Notes: See Table 4A. 
consumption expenditure as \% of GDP in regression (8), the results of other variables remain essentially unchanged. Finally, adjusting for capital in regression (9), the FDI variable turns out to be significant whereas the trade variable loses its statistical significance.

Several findings emerge as the results of these regressions. First, without gross capital formation as a control variable, the coefficients on trade are positively significant in all the System GMM models. In contrast, when the regressions include capital formation, the coefficients on trade lose their explanatory power. These results are consistent with the view that trade might be contributing to economic growth largely through investment, (for instance, in the form of increase in imports of capital goods or investment related to the expansion in exports). Wacziarg (2001) employs a three-stage least squares (3SLS) model in order to evaluate simultaneously the mechanism through which trade would bring growth. He considers six channel variables, namely improved macroeconomic policies, reduced distortions, government consumption, technological transmissions (proxied by manufactured exports), investment rate and FDI, through which trade affects growth. Wacziarg (2001)'s model confirms that trade has a strong positive impact on economic growth, and that the accelerated accumulation of physical capital accounts for more than half of the total effect of trade policy on growth. Levine and Renelt (1992) also identify a positive, robust correlation between growth and the share of investment in GDP and between the investment share and the ratio of

Figure 2. Relationship between Trade, FDI Inflow and Gross Capital Formation Figure 2.A. Trade and Gross Capital Formation

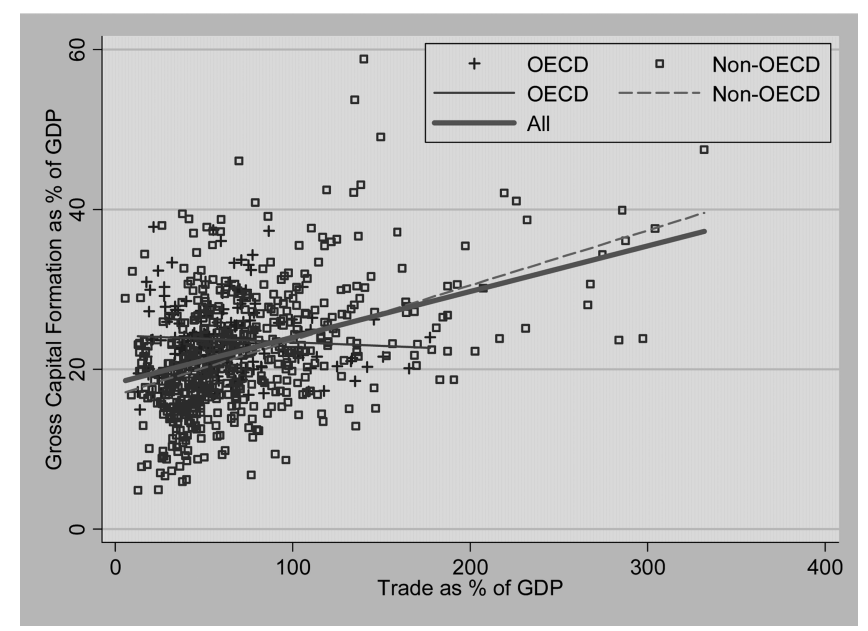


Figure 2B. Trade and FDI Inflow

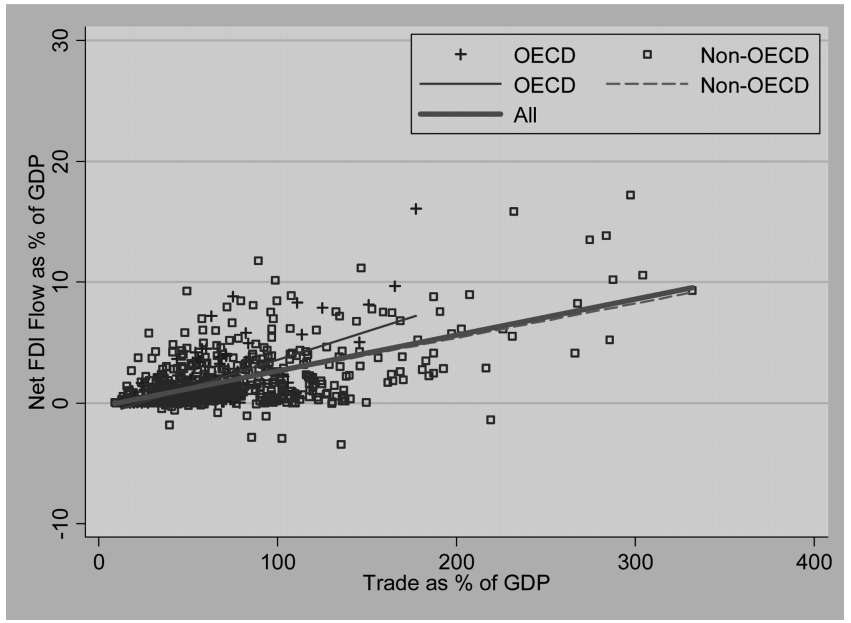

Figure 2C. Gross Capital Formation and FDI Inflow

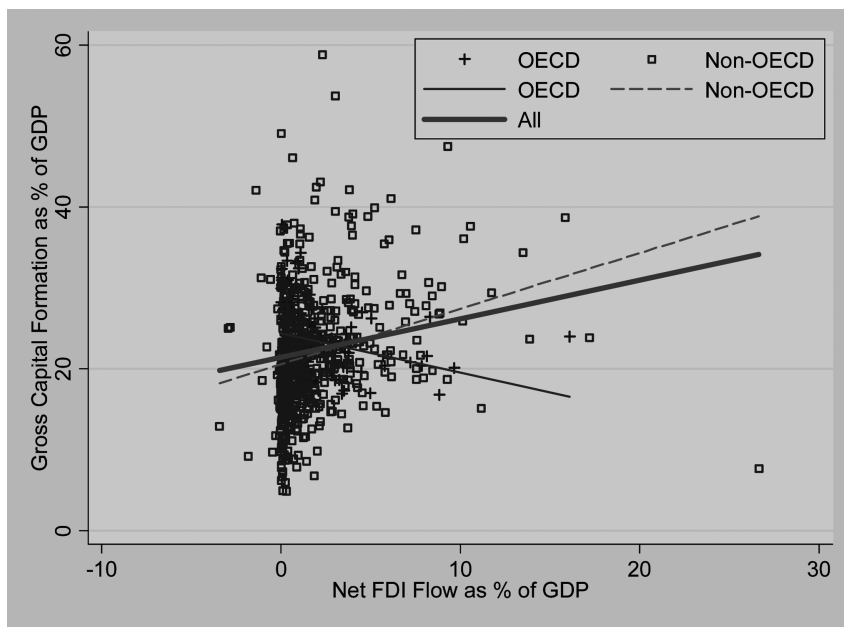

trade to GDP.

In order to investigate how trade and capital formation are correlated in my sample, Figure. 2.A plots the relationship between these variables for the observations in my dataset.

Overall, trade is shown to be positively associated with capital formation.

${ }^{10}$ The OECD countries are defined as the current member countries for which the data are available, namely,-Australia, Austria, Belgium, Canada, Denmark, Finland, France, Germany, Greece, Hungary, Iceland, Ireland, Italy, Japan, Korea, Mexico, Netherlands, New Zealand, Norway, Poland, Portugal, Spain, Sweden, Switzerland, Turkey, United Kingdom, and the United States. Czech Republic, Luxembourg, and Slovak Republic are not included due to the unavailability of the data. 
Evaluating the data by the subsets of $\mathrm{OECD}^{10}$ and non-OECD economies, it is revealed that there is a positive robust link between trade and capital in non-OECD countries, but that the correlation is close to zero for OECD countries.

Second, when both trade and FDI variables are included in the regressions, one of these variables tends to lose statistical significance. Trade and FDI are linked in many different ways. First, both variables might reflect the general openness of a country (e.g. if a country "opens up" and liberalizes trade and investment regimes simultaneously). Second, increases in trade may be directly caused by increases in FDI, due to a much greater propensity to trade of foreign firms relative to domestic firms. ${ }^{11}$ Third, the association might reflect features of FDI, e.g. so-called "horizontal" FDI to serve a protected host-country market vs. "vertical" FDI that is integrated into the global production network of the parent multinationals. With "horizontal" FDI, as FDI may occur to save trade costs, FDI acts mainly as a substitute for trade. In contrast, in the context of "vertical" integration strategies in which multinationals locate their production activities across different countries taking advantage of international factor price differences, trade and FDI tend to be complements. Figure 2.B reveals a positive correlation between trade and FDI for both OECD and non-OECD economies.

Third, the coefficients on FDI are sensitive to the inclusion of the capital variable. The effects of FDI on capital formation can be either positive or negative. On the positive side, foreign firms, especially FDI in the form of greenfield investments, ${ }^{12}$ may contribute directly to domestic capital formation. As foreign firms are more involved in trade relative to domestic firms, FDI might promote trade-induced investments. They might also indirectly stimulate domestic investment through backward and forward linkages. On the other hand, FDI might be harmful to domestic capital formation by crowding out domestic investments and forcing inefficient firms out of business. Policies offering preferential tax treatment and other incentives to attract FDI may result in forgone public revenues and introduce distortions affecting domestic investments.

\footnotetext{
${ }^{11}$ According to the Enterprise Surveys of 96 countries conducted by World Bank/IFC (www. enterprisesurveys.org), foreign firms are engaged in trade much more than domestic firms. The shares of foreign firms (domestic firms) who directly import and export are 68.0 per cent (43.3 per cent) and 43.3 per cent (18.1 per cent) respectively (author's calculation based on Enterprise Surveys).

${ }^{12}$ In the short-run, greenfield FDI, or investment in new projects, usually contributes directly to the stock of productive capital in the host country (by setting up a new production base for instance). In contrast, a merger or acquisition (M\&A) generally adds to "foreign-owned" capital stock, but does not represent an immediate addition to the capital stock of countries. In the long-run, the impacts of FDI on capital formation are difficult to distinguish by mode of entry (UNCTAD, 2006).
} 
Figure 2.C plots the relationship between FDI inflow and gross capital formation. Overall, there exists a positive correlation between these variables. Whereas the link is found to be positive for non-OECD economies, the association appears to be negative for OECD economies. Some studies suggest that FDI may play a greater role in the capital formation in developing countries since the latter countries rely more on foreign capital as sources of funds and more FDI takes the form of greenfield investments. In contrast, developed countries have access to their own capital markets and most FDI in these countries represents the purchase of existing assets and companies. De Mello (1997) argues that the extent to which FDI is growth-enhancing is influenced by the degree of complementarity and substitution between FDI and domestic investment in the short run. In developing countries (technological followers), according to de Mello, FDI may be promoted as a means to foster capital accumulation as complementarity of technology would lead to a more diversified production base. In contrast, in more technologically advanced economies, a "Shumpeterian view of FDI-related innovative investment" which implies creative destruction through substitution (de Mello, p.20), might be more relevant since more efficient technologies embodied in FDI may lead to faster technological obsolescence. Based on data for 50 countries, Wang (2003) finds a negative contemporaneous effect of FDI inflows on domestic investment in OECD countries. She also demonstrates that the cumulative long-run effect of FDI inflows on a host country's domestic investment tends to be positive in non-OECD countries and neutral in OECD countries. Table 4.B demonstrates the regression results for a subset of non-OECD economies. ${ }^{13}$ The results demonstrate a robust positive relationship between FDI inflow and growth with the coefficients on FDI of all the models becoming positively significant. ${ }^{14}$

Finally, the positive association between education and growth in System GMM models is robust to the inclusion of various control variables with the coefficients on education of all the models revealing a significantly positive relationship. ${ }^{16}$ The magnitudes of the effect of schooling on growth vary depending on the control variables. For instance, controlling for physical capital and other variables in

\footnotetext{
${ }^{13}$ System GMM estimator is designed for situations with "Small T, large N" panels meaning few time periods and many individuals (Roodman, 2006). For the subset of OECD countries, it became impossible to run the System GMM regressions due to the reduced sample size. See Appendix Table A for the results of OLS and fixed effect models.

${ }^{14}$ Howwever, further robustness analyses reveal that the coefficients of FDI become insignificant when inflation is not included in the regressions. Thus, it should not be assumed that FDI is always growth enhancing in developing countries.
} 
regression (9), an increase by one year in the average education years of the population over age 15 is associated with about $.67 \%$ faster annual growth in per capita GDP. These findings contrast with the results obtained from the withincountry fixed effects models where none of the coefficients on education reveals any statistically significant relationship (see Appendix Table A). This exercise suggests that the results of the coefficients on education obtained from withincountry panel data models need to be interpreted with caution since the latter models wipe out the information on cross-country variation in the levels of educational attainment.

A similar insight would be relevant for the models derived from growth accounting exercises since the growth rates of human capital also fail to incorporate cross country variation in education levels. For instance, Benhabib and Spiegel (1994) estimate growth accounting regressions relating the growth rate of GDP to the log change in years of schooling and find insignificant and usually negative coefficients on human capital growth rates. However, specifying an alternative model in which the growth rate of technological progress depends on a country's human capital stock level, Benhabib and Spiegel find a positive relationship between human capital and economic growth. They in turn conclude that education is not directly important as a factor of production and that human capital affects growth by promoting technological innovation and facilitating adoption of technology from abroad. However, I cast some doubt on Benhabib and Spiegel's conclusion that human capital is not a productive input in the production function since, when the log level of GDP is regressed on the log level of education, the coefficient on education turns out to be positive and highly significant. ${ }^{15}$

\footnotetext{
${ }^{15}$ Assuming a simplified version of the production function in which per capita income $\left(Y_{\mathrm{t}}\right)$ is a function of physical capital $\left(K_{t}\right)$ and human capital $\left(H_{t}\right), Y_{t}=g\left(K_{t}, H_{t}\right)$, and taking log differences, I estimate the following relationship for my sample: $\Delta \log Y_{t}=0.087^{* * *}+0.22^{* * *} \Delta \log K_{t}-0.16^{* * *} \Delta \log H_{t}$ $\begin{array}{lll}(0.0095) \quad(0.031) \quad(0.044) & 0\end{array}$

$\left(\mathrm{R}^{2}=0.12\right.$; number of observations $=560$; robust standard errors are in parentheses $)$

Similar to the findings of Benhabib and Spiegel and others, the coefficient on log difference in human capital is found to be significantly negative.

However, when the log level of income per capita is regressed on the log level of human capital, the coefficient on the log level of education turns out to be highly positively significant as shown below. $\log Y_{t}=3.70^{* * *}+0.48^{*} \log K_{t}+1.71^{* * *} \log H_{t}$

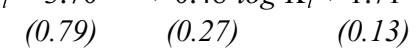
$\left(\mathrm{R}^{2}=0.54\right.$; number of observations $=667$; robust standard errors are in parentheses $)$
} 


\section{Revisiting Borensztein, de Gregorio and Lee (1998)}

Borensztein et al. (1998) test the impact of FDI on economic growth via transfer of technology dealing with data on FDI flows from industrial countries to 69 developing countries. They find a positively significant coefficient for the interaction term between FDI and schooling and suggest that the beneficial effects of FDI in terms of growth hold only when the host country has a minimum threshold stock of human capital. However, a recent study by Carkovic and Levine (2005) finds little evidence that FDI would affect economic growth even allowing for the interaction between FDI and human capital.

Borensztein et al.'s findings lead to a question whether some minimum level of human capital is a prerequisite for a country to reap any benefit from FDI. Based on case study evidence involving poorer developing countries, Moran (2005) suggests that allowing foreign firms to invest in economic sectors which employ the low-skilled workers in the early stages of export-led growth ${ }^{16}$ might provide positive impacts to the least developed countries in terms of generating employment opportunities and export revenues. As foreign firms have an incentive to locate labor-intensive activities in low-wage countries either in the context of vertical integration strategy ${ }^{17}$ or "export platform" operations, FDI may play a key role in utilizing efficiently low-skilled labor in which the least developed economies possess a comparative advantage. Applying the Smith-Myint model of "vent for surplus" to China, Fu and Balasubramanyam (2005) find that the expansion of exports from labor-intensive manufacturing, assisted by FDI, has promoted the growth of industrial output and accelerated the transfer of surplus labor from the agricultural to the export sector.

Slaughter (2002) suggests that FDI might contribute to a host country's good macro environment in which fiscal policy drives productive investments, through for instance contributing to host-country revenues. Botswana's FDI experience can be cited as an example that even a least developed country with a minimal initial stock of human capital might reap such benefits if a country has strong institutions.

\footnotetext{
${ }^{16}$ Balasubramanyam, Salisu, and Sapsford (1996) find that the beneficial effect of FDI on economic growth is stronger when developing countries pursue the export promoting (EP) strategy rather than the import substituting (IS) strategy.

${ }^{17}$ Using firm-level data on U.S. multinationals, Hanson, Mataloni and Slaughter (2005) examine the behavior of multinational firms locating input processing in their foreign affiliates. They find that the demand for imported inputs by U.S. multinationals is higher when affiliates face lower wages for lessskilled labor.
} 
Botswana is among the fastest growing economies (the second fastest after China in my sample) with an average annual real per capita GDP growth rate of $6.8 \%$ for the past 35 years. Starting as a very poor nation at independence in 1966 with per capita income of merely $\$ 312,{ }^{18}$ Botswana now belongs to the upper-middle income countries with real per capita GDP of \$3,683.9 in 2004 (The World Bank). Several studies document the presence of good institutions among the causes of its high economic growth (Acemoglu, Johnson, and Robinson, 2001; Mehlum, Moene, and Torvik, 2006; Olsson, 2006). Soon after the Kimberlite diamond pipes were found in the early 1970s, the Botswanan government formed a joint venture with the South African firm De Beers, which has a dominant position in the global diamond market. ${ }^{19}$ Botswana in turn invested its revenues from diamonds in a socially efficient way in public goods such as infrastructure, health and education (Acemoglu et al., 2001). For instance, Botswana accumulated human capital at a much faster rate than the world average with the average education years of its population increasing from 2.0 years in 1970 to 6.3 years in 2000 (Barro and Lee, 2000).

Blonigen and Wang (2005) argue that it is inappropriate to pool developing and developed countries in empirical analyses since there is a systematic difference in the determinants and effects of FDI between these two groups of countries. They test a hypothesis that the contrasting results between Borensztein et al. (1998) and Carkovic and Levine (2005) might be attributed to the different coverage of host countries included in their samples. ${ }^{20}$ Extending Borensztein et al.'s dataset adding developed countries as host countries, and observing that the interaction term loses its significance, Blonigen and Wang argue that Borensztein et al.'s conclusions are supported only for developing host countries. In the next subsection, I extend Borenstzein et al./Blonigen and Wang's analyses and investigate what happens if the source countries are extended to both OECD and non-OECD countries using their actual dataset.

Column 1 on Table 5 reproduces Borenstzein et al. 's results of the impact of FDI from OECD to developing countries (Regression 1.3 in Table 1, p.124) using the

\footnotetext{
${ }^{18} 2000$ constant price.

${ }^{19}$ See Olsson (2006) for the crucial role of Botswana's joint venture with De Beers in securing revenue from diamond production.

${ }^{20}$ Carkovic and Levine (2005) deal with both developing and developed countries as source and destination of FDI. Borensztein et al. investigate only the FDI originated in OECD countries to developing countries assuming that FDI flows from industrialized to developing countries to "close the technological gap" (Borensztein et al. , 1998, p.122).
} 
Table 5. Replication and Extension of Borensztein et al. (1998)

\begin{tabular}{lccc}
\hline & $(1)$ & $(2)$ & $(3)$ \\
\hline \multirow{2}{*}{ Log of initial GDP } & $-0.12^{* * *}$ & $-0.0099^{* * *}$ & $-0.014^{* * *}$ \\
& $(0.0038)$ & $(0.0032)$ & $(0.0040)$ \\
Schooling $^{1}$ & $0.012^{* * *}$ & $0.0077^{* *}$ & $0.021^{* * *}$ \\
& $(0.0045)$ & $(0.0034)$ & $(0.0058)$ \\
Government Consumption & $-0.080^{* *}$ & $-0.10^{* * *}$ & $-0.11^{* * *}$ \\
& $(0.033)$ & $(0.031)$ & $(0.034)$ \\
Log(1+black market premium) & $-0.018^{* * *}$ & $-0.019^{* * *}$ & $-0.016^{* * *}$ \\
& $(0.0054)$ & $(0.0051)$ & $(0.0055)$
\end{tabular}

FDI from OECD to 69 Developing Countries

$\begin{array}{ll} & -0.83 \\ & (0.72) \\ \text { FDI } & 1.61^{* * *} \\ & (0.61)\end{array}$

FDI from OECD to both OECD and non-OECD Countries

$\begin{array}{lc}\text { FDI } & 0.21 \\ & (0.59) \\ \text { FDI*Schooling } & 0.14 \\ & (0.36)\end{array}$

FDI from both OECD and non-OECD to 69 Developing Countries

\begin{tabular}{|c|c|c|c|}
\hline \multicolumn{3}{|l|}{ FDI } & $\begin{array}{l}0.55^{* *} \\
(0.26)\end{array}$ \\
\hline FDI*Schooling & & & $\begin{array}{l}-0.23 \\
(0.22)\end{array}$ \\
\hline Number of Countries & 69 & 88 & 69 \\
\hline$R^{2}-1970-79$ & 0.39 & 0.28 & 0.36 \\
\hline$R^{2}-1980-89$ & 0.16 & 0.12 & 0.17 \\
\hline Goodness of Fit - $\chi^{2}(p$-value $)$ & $\begin{array}{c}50.13 \\
(0.000)\end{array}$ & $\begin{array}{c}42.00 \\
(0.000)\end{array}$ & $\begin{array}{c}45.55 \\
(0.000)\end{array}$ \\
\hline
\end{tabular}

Notes: The dependent variable is the per capita GDP growth rate. Standard errors are in parentheses. ${ }^{1}$ Schooling represents average years of the male secondary schooling aged over 25 . Seemingly Unrelated Regression (SUR) estimation was done constraining all the coefficients (except the constant) to be the same across the two decades.

Seemingly Unrelated Regression (SUR) techniques for the periods 1970s and 1980s.

The results demonstrate that whereas the coefficient on FDI is negative but insignificant, the interaction term is positively significant at the one $\%$ level. The values of these coefficients imply that the countries with male secondary school attainment above .52 will benefit from FDI, which is the identical result with Borenstzein et al. 's (p.125). Column 2 of Table 5 provides the results of the effects 
of FDI from OECD to both developed and developing economies as host countries using Blonigen and Wang's (2005) extended dataset. The results show much reduced and statistically insignificant coefficient estimates on FDI measures supporting Blonigen and Wang (2005)'s conclusion that FDI from developed countries affects growth conditioned on a sufficient level of human capital only in developing host countries.

Finally, Column 3 of Table 5 reports the results replacing the FDI variable with those from all the source countries to developing host countries. Whereas the coefficient on FDI is found to be positively significant at the five \% level, the coefficient on the interaction term becomes insignificant. These results imply that, once all the source countries are taken into consideration, the growth of developing countries is generally associated positively with FDI and that no evidence is found to support the existence of threshold level of schooling below which developing

Table 6. Regression Results with the Interaction Term

\begin{tabular}{|c|c|c|c|c|c|c|}
\hline & $\left(2^{\prime}\right)$ & $\left(4^{\prime}\right)$ & $\left(6^{\prime}\right)$ & $\left(7^{\prime}\right)$ & $\left(8^{\prime}\right)$ & $\left(9^{\prime}\right)$ \\
\hline Lagged log of GDP & $\begin{array}{l}1.05^{* * *} \\
(0.012)\end{array}$ & $\begin{array}{l}1.01^{* * *} \\
(0.027)\end{array}$ & $\begin{array}{l}0.96^{* * *} \\
(0.023)\end{array}$ & $\begin{array}{l}0.97^{* * *} \\
(0.028)\end{array}$ & $\begin{array}{l}0.98^{* * *} \\
(0.030)\end{array}$ & $\begin{array}{l}0.95^{* * *} \\
(0.019)\end{array}$ \\
\hline Average Education Years & & $\begin{array}{l}2.60^{*} \\
(1.50)\end{array}$ & $\begin{array}{l}2.36^{*} \\
(1.38)\end{array}$ & $\begin{array}{l}4.64^{* * *} \\
(1.56)\end{array}$ & $\begin{array}{c}4.34^{* * *} \\
(1.58)\end{array}$ & $\begin{array}{c}2.81^{* * *} \\
(1.07)\end{array}$ \\
\hline Inflation & & $\begin{array}{c}-0.0082^{* * *} \\
(0.00077)\end{array}$ & $\begin{array}{c}-0.0067^{* * *} \\
(0.0014)\end{array}$ & $\begin{array}{c}-0.0073^{* * *} \\
(0.0014)\end{array}$ & $\begin{array}{c}-0.0068^{* * *} \\
(0.0015)\end{array}$ & $\begin{array}{c}-0.0069^{* * *} \\
(0.0013)\end{array}$ \\
\hline Trade as $\%$ of GDP & & & & $\begin{array}{c}0.11^{* *} \\
(0.049)\end{array}$ & $\begin{array}{c}0.13^{* *} \\
(0.057)\end{array}$ & $\begin{array}{l}-0.024 \\
(0.026)\end{array}$ \\
\hline \multicolumn{7}{|l|}{ FDI Measures } \\
\hline FDI & $\begin{array}{l}2.24^{*} \\
(1.16)\end{array}$ & $\begin{array}{l}5.64^{* * *} \\
(1.11)\end{array}$ & $\begin{array}{c}1.28 \\
(0.95)\end{array}$ & $\begin{array}{l}5.70^{* * *} \\
(1.31)\end{array}$ & $\begin{array}{l}5.46^{* * *} \\
(1.10)\end{array}$ & $\begin{array}{c}1.39 \\
(0.87)\end{array}$ \\
\hline FDI*Schooling & $\begin{array}{l}-0.29^{*} \\
(0.16)\end{array}$ & $\begin{array}{c}-0.67^{* * *} \\
(0.15)\end{array}$ & $\begin{array}{l}-0.10 \\
(0.12)\end{array}$ & $\begin{array}{c}-0.81^{* * *} \\
(0.18)\end{array}$ & $\begin{array}{c}-0.76^{* * *} \\
(0.15)\end{array}$ & $\begin{array}{l}-0.082 \\
(0.11)\end{array}$ \\
\hline Government Consumption & & & & & $\begin{array}{l}-0.75^{* *} \\
(0.32)\end{array}$ & \\
\hline Gross Capital Formation & & & $\begin{array}{l}1.46^{* * *} \\
(0.19)\end{array}$ & & & $\begin{array}{l}1.42^{* * *} \\
(0.18)\end{array}$ \\
\hline M2 & 0.372 & 0.920 & 0.676 & 0.744 & 0.882 & 0.816 \\
\hline Hansen & 0.352 & 0.260 & 0.226 & 0.156 & 0.421 & 0.338 \\
\hline Number of Observation & 656 & 613 & 606 & 607 & 605 & 605 \\
\hline Number of Countries & 104 & 102 & 102 & 102 & 102 & 102 \\
\hline Number of Instruments & 88 & 92 & 79 & 79 & 91 & 91 \\
\hline
\end{tabular}

Notes: The models in Table 4A were re-estimated including the interaction term between schooling and FDI. 
host countries cease to benefit.

It is not the purpose of this exercise to argue that human capital is not important interactively with FDI. Perhaps, Borenstzein et al. 's conclusions may be valid for the technology transfer channel from developed countries but developing source countries may contribute to growth in other developing countries probably due to the use of technology that is more compatible with host-country educational levels. In other words, this paper suggests that there appears to be a variety of channels through which FDI can affect growth and that the role of human capital are likely to differ depending on different channels, industries, and host country policies and institutional capabilities.

Table 6 demonstrates the results of System GMM models re-estimating the regressions in Table 4.A including the interaction term between schooling and FDI.

Surprisingly, the coefficients on interaction terms turn out to be negatively significant in four out of the six models implying that the growth effect of FDI is greater for countries with lower human capital. ${ }^{21}$ These findings may appear puzzling, but are consistent with Carkovic and Levine's (2005). ${ }^{22}$ A potential explanation is that the interaction term may have captured an overall tendency for the impacts of FDI to be greater in developing countries (with less human capital) than in developed countries (with more human capital). The results of the impacts of FDI vary depending on the periods included. Excluding the most recent three periods, namely 1989-2004, the coefficients on the interaction term turn out to be insignificant (not reported). Perhaps, a variety of changing characteristics of FDI including a greater level of cross-border mergers and acquisitions (M\&As) relative to the earlier periods, and increasing participation of developing economies as sources of $\mathrm{FDI}^{23}$ (UNCTAD, 2006) - may have been altering the impacts of FDI in host countries over time.

\footnotetext{
${ }^{21}$ The qualitative results are similar when I use OLS, SUR and fixed effects models.

${ }^{22}$ Investigating 70 countries over the periods 1960 to 1995 , Carkovic and Levine (2005) find that the coefficients on FDI*education are either insignificant or negatively significant in their System GMM models.

${ }^{23}$ For low-income developing countries, FDI from developing countries accounts for a large share of total FDI flows. FDI by developing countries might have a greater employment-generating potential relative to those by developed countries since they may be oriented more towards labor-intensive industries and may use simpler technologies. The example of such FDI is the emergence of East Asian developing countries as foreign investors in labor-intensive sectors in Asia (UNCTAD, 2006).
} 


\section{Conclusion}

This paper revisits the relationship between openness, education and economic growth for 106 countries over the periods 1969-2004 using the System GMM approach.

In terms of the linkages between openness and growth, the system GMM estimators provide support for some of the earlier findings. Whereas there are usually positive ties between trade and growth, the coefficient on trade loses statistical significance when the regressions include capital formation. The latter result is consistent with the earlier research findings that trade is largely linked to higher growth via investment (Wacziarg, 2001; Levine and Renelt, 1992).

There generally exists a positive relationship between FDI inflow and economic growth for a subset of non-OECD countries. This may be partly because FDI has in average positive impacts on host-countries' capital formation in developing countries (de Mello 1997; Wang, 2003). However, the paper does not reveal clear insights on how FDI and education interact to affect economic growth. In my regressions, the coefficients for the interaction term between FDI and education are found to be sensitive to the coverage of source and host countries and the periods included. The paper suggests that there appears to be a variety of channels through which FDI can affect growth and that the role of human capital are likely to differ depending on different channels, industries, and host country policies and institutional capabilities.

Finally, the System GMM approach is found to improve substantially the estimate of the impacts of education on growth relative to the models which focus on the changes in educational attainment. The effect of education on economic growth has been debated in the literature. Whereas earlier studies identified the positive impacts of the initial level of education on economic growth (e.g. Barro, 1991), some influential papers which relate economic growth and education growth find insignificant and even negative coefficients on education (e.g. Benhabib and Spiegel, 1994; Pritchett, 2001). This paper hypothesizes that these mixed results are attributed to the characteristics of the data, i.e., whereas there exists a positive relationship between the levels in educational attainment and economic growth, there is little systematic variation in the changes in education across countries (see Figure 1). The System GMM approach is shown to be better suited to the actual data: once adding information on cross country variation in education levels to those on within-country changes in education, the System 
GMM estimator reveals a strong positive relationship between education and subsequent growth. These exercises have important policy implications. Given fiscal budget constraints, there exists a potential danger that little or even negative contribution of education to economic growth may discourage public investment in education. This paper emphasizes that there indeed exists a robust positive association between education and subsequent growth and suggests that the investment in schooling be among the top priorities in countries' development strategies.

\section{Acknowledgements}

I am grateful to Terence Agbeyegbe for suggesting using the System GMM approach, Miao Wang for sharing the FDI data, Jonathan Nelson, Wim Vijverberg and anonymous referees for very useful comments. Any remaining errors are mine.

Received 13 March 2008, Revised 26 October 2009, Accepted 30 October 2009

\section{Data Appendix}

The following data are extracted from the World Development Indicators (the World Bank) from 1969 to 2004: real per capita GDP in constant 2000 prices; inflation rate in consumer prices, trade (imports plus exports) as \% of GDP; government consumption as per cent of GDP; and gross capital formation as per cent of GDP. The data for FDI inflow as per cent of GDP are taken from Foreign Direct Investment (FDI) Database of UNCTAD. The averages of male and female schooling years for the population over age 15 are computed from Barro and Lee's dataset (2000). I am grateful for Miao Wang for providing with the FDI data used for Borensztein et al. (1998) and Blonigen and Wang (2005)'s studies. 
Table A. Results of Education and Openness Variables Estimated by OLS and Fixed Effects Models

\begin{tabular}{|c|c|c|c|c|c|c|c|c|c|c|c|c|}
\hline \multirow{2}{*}{ Model } & \multicolumn{6}{|c|}{ Variables Included } & \multicolumn{3}{|c|}{ Pooled OLS } & \multicolumn{3}{|c|}{ Fixed effects } \\
\hline & $\begin{array}{l}\text { Lagged } \\
\text { GDP }\end{array}$ & $\begin{array}{l}\text { Educa- } \\
\text { tion }\end{array}$ & Trade & FDI & Infl. & CapitalGov & $\begin{array}{l}\text { Educa- } \\
\text { tion }\end{array}$ & FDI & Trade & Education & FDI & Trade \\
\hline \multicolumn{13}{|c|}{ Full Sample } \\
\hline (1) & $\mathrm{x}$ & & $\mathrm{x}$ & & & & & & $\begin{array}{l}0.059^{* * *} \\
(0.015)\end{array}$ & & & $\begin{array}{l}0.19^{* * *} \\
(0.039)\end{array}$ \\
\hline (2) & $\mathrm{x}$ & & & $\mathrm{x}$ & & & & $\begin{array}{c}0.66 \\
(0.52)\end{array}$ & & & $\begin{array}{l}2.17^{* * *} \\
(0.64)\end{array}$ & \\
\hline (3) & $\mathrm{x}$ & $\mathrm{x}$ & $\mathrm{x}$ & & $\mathrm{x}$ & & $\begin{array}{l}1.95^{* * *} \\
(0.74)\end{array}$ & & $\begin{array}{c}0.050^{* * *} \\
(0.016)\end{array}$ & $\begin{array}{c}0.40 \\
(1.09)\end{array}$ & & $\begin{array}{l}0.17^{* * *} \\
(0.046)\end{array}$ \\
\hline (4) & $\mathrm{x}$ & $\mathrm{x}$ & & $\mathrm{x}$ & $\mathrm{x}$ & & $\begin{array}{l}1.84^{* *} \\
(0.73)\end{array}$ & $\begin{array}{l}1.26^{* * *} \\
(0.28)\end{array}$ & & $\begin{array}{c}0.31 \\
(1.10)\end{array}$ & $\begin{array}{l}1.50^{* * *} \\
(0.32)\end{array}$ & \\
\hline (5) & $\mathrm{x}$ & $\mathrm{x}$ & $\mathrm{x}$ & & $\mathrm{x}$ & $\mathrm{X}$ & $\begin{array}{l}1.72^{* * *} \\
(0.57)\end{array}$ & & $\begin{array}{l}0.0087 \\
(0.014)\end{array}$ & $\begin{array}{c}0.76 \\
(1.06)\end{array}$ & & $\begin{array}{l}0.12^{* * *} \\
(0.044)\end{array}$ \\
\hline (6) & $\mathrm{x}$ & $\mathrm{x}$ & & $\mathrm{x}$ & $\mathrm{x}$ & $\mathrm{X}$ & $\begin{array}{l}1.66^{* * *} \\
(0.58)\end{array}$ & $\begin{array}{l}0.71^{* * *} \\
(0.23)\end{array}$ & & $\begin{array}{c}0.65 \\
(1.03)\end{array}$ & $\begin{array}{l}1.23^{* * *} \\
(0.31)\end{array}$ & \\
\hline (7) & $\mathrm{x}$ & $\mathrm{x}$ & $\mathrm{x}$ & $\mathrm{x}$ & $\mathrm{x}$ & & $\begin{array}{l}1.85^{* *} \\
(0.73)\end{array}$ & $\begin{array}{l}1.08^{* * *} \\
(0.38)\end{array}$ & $\begin{array}{c}0.017 \\
(0.019)\end{array}$ & $\begin{array}{c}0.30 \\
(1.15)\end{array}$ & $\begin{array}{l}1.25^{* * *} \\
(0.33)\end{array}$ & $\begin{array}{l}0.15^{* * *} \\
(0.043)\end{array}$ \\
\hline (8) & $\mathrm{x}$ & $\mathrm{x}$ & $\mathrm{x}$ & $\mathrm{x}$ & $\mathrm{x}$ & $\mathrm{x}$ & $\begin{array}{l}1.89^{* *} \\
(0.74)\end{array}$ & $\begin{array}{l}1.02^{* *} \\
(0.40)\end{array}$ & $\begin{array}{c}0.022 \\
(0.019)\end{array}$ & $\begin{array}{c}0.33 \\
(1.16)\end{array}$ & $\begin{array}{l}1.23^{* * *} \\
(0.33)\end{array}$ & $\begin{array}{l}0.15^{* * *} \\
(0.043)\end{array}$ \\
\hline (9) & $\mathrm{x}$ & $\mathrm{x}$ & $\mathrm{x}$ & $\mathrm{x}$ & $\mathrm{x}$ & $\mathrm{X}$ & $\begin{array}{l}1.64^{* * * *} \\
(0.56)\end{array}$ & $\begin{array}{l}0.98^{* * *} \\
(0.30)\end{array}$ & $\begin{array}{l}-0.023 \\
(0.016)\end{array}$ & $\begin{array}{c}0.68 \\
(1.07)\end{array}$ & $\begin{array}{l}1.07^{* * *} \\
(0.29)\end{array}$ & $\begin{array}{c}0.10^{* *} \\
(0.040)\end{array}$ \\
\hline \multicolumn{13}{|c|}{ Non-OECD Countries } \\
\hline (1) & $\mathrm{x}$ & & $\mathrm{x}$ & & & & & & $\begin{array}{c}0.087^{* * *} \\
(0.019)\end{array}$ & & & $\begin{array}{l}0.19^{* * *} \\
(0.040)\end{array}$ \\
\hline (2) & $\mathrm{x}$ & & & $\mathrm{x}$ & & & & $\begin{array}{c}0.87 \\
(0.69)\end{array}$ & & & $\begin{array}{l}2.41^{* * *} \\
(0.70)\end{array}$ & \\
\hline (3) & $\mathrm{x}$ & $\mathrm{x}$ & $\mathrm{x}$ & & $\mathrm{x}$ & & $\begin{array}{l}2.83^{* * *} \\
(0.90)\end{array}$ & & $\begin{array}{c}0.064^{* * *} \\
(0.020)\end{array}$ & $\begin{array}{l}-0.86 \\
(1.06)\end{array}$ & & $\begin{array}{l}0.16^{* * *} \\
(0.047)\end{array}$ \\
\hline (4) & $\mathrm{x}$ & $\mathrm{x}$ & & $\mathrm{x}$ & $\mathrm{x}$ & & $\begin{array}{l}2.82^{* * *} \\
(0.78)\end{array}$ & $\begin{array}{l}1.85^{* * *} \\
(0.34)\end{array}$ & & $\begin{array}{l}-0.64 \\
(1.19)\end{array}$ & $\begin{array}{l}1.70^{* * *} \\
(0.38)\end{array}$ & \\
\hline (5) & $\mathrm{x}$ & $\mathrm{x}$ & $\mathrm{x}$ & & $\mathrm{x}$ & $X$ & $\begin{array}{l}2.57^{* * *} \\
(0.67)\end{array}$ & & $\begin{array}{c}0.015 \\
(0.018)\end{array}$ & $\begin{array}{l}-0.088 \\
(1.16)\end{array}$ & & $\begin{array}{l}0.093^{* *} \\
(0.039)\end{array}$ \\
\hline (6) & $\mathrm{x}$ & $\mathrm{x}$ & & $\mathrm{x}$ & $\mathrm{x}$ & $\mathrm{X}$ & $\begin{array}{l}2.47^{* * *} \\
(0.61)\end{array}$ & $\begin{array}{l}1.15^{* * *} \\
(0.30)\end{array}$ & & $\begin{array}{l}-0.22 \\
(1.13)\end{array}$ & $\begin{array}{l}1.33^{* * *} \\
(0.38)\end{array}$ & \\
\hline (7) & $\mathrm{x}$ & $\mathrm{x}$ & $\mathrm{x}$ & $\mathrm{x}$ & $\mathrm{x}$ & & $\begin{array}{l}2.80^{* * * *} \\
(0.81)\end{array}$ & $\begin{array}{l}1.75^{* * *} \\
(0.45)\end{array}$ & $\begin{array}{c}0.013 \\
(0.022)\end{array}$ & $\begin{array}{l}-0.80 \\
(1.15)\end{array}$ & $\begin{array}{l}1.58^{* * *} \\
(0.42)\end{array}$ & $\begin{array}{l}0.14^{* * *} \\
(0.047)\end{array}$ \\
\hline (8) & $\mathrm{x}$ & $\mathrm{x}$ & $\mathrm{x}$ & $\mathrm{x}$ & $\mathrm{x}$ & $\mathrm{x}$ & $\begin{array}{l}2.81^{* * *} \\
(0.82)\end{array}$ & $\begin{array}{l}1.66^{* * *} \\
(0.47)\end{array}$ & $\begin{array}{c}0.019 \\
(0.022)\end{array}$ & $\begin{array}{l}-0.79 \\
(1.15)\end{array}$ & $\begin{array}{l}1.55^{* * *} \\
(0.42)\end{array}$ & $\begin{array}{l}0.14^{* * *} \\
(0.047)\end{array}$ \\
\hline (9) & $\mathrm{x}$ & $\mathrm{x}$ & $\mathrm{x}$ & $\mathrm{x}$ & $\mathrm{x}$ & $\mathrm{X}$ & $\begin{array}{l}2.51^{* * *} \\
(0.60)\end{array}$ & $\begin{array}{l}1.45^{* * *} \\
(0.35)\end{array}$ & $\begin{array}{l}-0.027 \\
(0.018)\end{array}$ & $\begin{array}{l}-0.20 \\
(1.17)\end{array}$ & $\begin{array}{l}1.24^{* * *} \\
(0.38)\end{array}$ & $\begin{array}{l}0.083^{* *} \\
(0.041)\end{array}$ \\
\hline \multicolumn{13}{|c|}{ OECD Countries } \\
\hline (1) & $\mathrm{x}$ & & $\mathrm{x}$ & & & & & & $\begin{array}{c}0.056 \\
(0.033)\end{array}$ & & & $\begin{array}{c}0.23^{* *} \\
(0.093)\end{array}$ \\
\hline (2) & $\mathrm{x}$ & & & $\mathrm{x}$ & & & & $\begin{array}{c}0.17 \\
(0.73)\end{array}$ & & & $\begin{array}{c}0.64 \\
(0.72)\end{array}$ & \\
\hline (3) & $\mathrm{x}$ & $\mathrm{x}$ & $\mathrm{x}$ & & $\mathrm{x}$ & & $\begin{array}{l}-0.20 \\
(0.57)\end{array}$ & & $\begin{array}{c}0.046 \\
(0.034)\end{array}$ & $\begin{array}{c}1.49 \\
(1.45)\end{array}$ & & $\begin{array}{c}0.25^{* *} \\
(0.095)\end{array}$ \\
\hline
\end{tabular}


Table A. Results of Education and Openness Variables Estimated by OLS and Fixed Effects Models (Continued)

\begin{tabular}{|c|c|c|c|c|c|c|c|c|c|c|c|c|}
\hline \multicolumn{7}{|c|}{ Variables Included } & \multicolumn{3}{|c|}{ Pooled OLS } & \multicolumn{3}{|c|}{ Fixed effects } \\
\hline Model I & $\begin{array}{c}\text { Lagged } \\
\text { GDP }\end{array}$ & $\begin{array}{l}\text { Edu- } \\
\text { cation }\end{array}$ & & rade & FDI Infl. & CapitalGov & Education & FDI & Trade & $\begin{array}{l}\text { Educa- } \\
\text { tion }\end{array}$ & FDI & Trade \\
\hline (4) & $\mathrm{x}$ & $\mathrm{x}$ & & $\mathrm{x}$ & $\mathrm{x}$ & & $\begin{array}{l}-0.23 \\
(0.67)\end{array}$ & $\begin{array}{c}0.16 \\
(0.76)\end{array}$ & & $\begin{array}{c}1.05 \\
(1.31)\end{array}$ & $\begin{array}{c}0.78 \\
(0.69)\end{array}$ & \\
\hline (5) & $\mathrm{x}$ & $\mathrm{x}$ & $\mathrm{x}$ & & $\mathrm{x}$ & $X$ & $\begin{array}{l}-0.33 \\
(0.54)\end{array}$ & & $\begin{array}{c}0.042 \\
(0.034)\end{array}$ & $\begin{array}{c}1.04 \\
(1.48)\end{array}$ & & $\begin{array}{c}0.18 \\
(0.11)\end{array}$ \\
\hline (6) & $\mathrm{x}$ & $\mathrm{x}$ & & $\mathrm{x}$ & $\mathrm{x}$ & X & $\begin{array}{l}-0.34 \\
(0.57)\end{array}$ & $\begin{array}{c}0.33 \\
(0.63)\end{array}$ & & $\begin{array}{c}0.91 \\
(1.39)\end{array}$ & $\begin{array}{c}0.73 \\
(0.52)\end{array}$ & \\
\hline (7) & $\mathrm{x}$ & $\mathrm{x}$ & $\mathrm{x}$ & $\mathrm{x}$ & $\mathrm{x}$ & & $\begin{array}{l}-0.14 \\
(0.62)\end{array}$ & $\begin{array}{c}-0.50 \\
(0.71)\end{array}$ & $\begin{array}{l}0.079^{* *} \\
(0.037)\end{array}$ & $\begin{array}{c}0.85 \\
(1.47)\end{array}$ & $\begin{array}{c}-0.0043 \\
(0.38)\end{array}$ & $\begin{array}{l}0.27^{* * *} \\
(0.094)\end{array}$ \\
\hline (8) & $\mathrm{x}$ & $\mathrm{x}$ & $\mathrm{x}$ & $\mathrm{x}$ & $\mathrm{x}$ & $\mathrm{x}$ & $\begin{array}{l}-0.16 \\
(0.59)\end{array}$ & $\begin{array}{c}-0.51 \\
(0.63)\end{array}$ & $\begin{array}{l}0.091^{* *} \\
(0.036)\end{array}$ & $\begin{array}{c}1.41 \\
(1.40)\end{array}$ & $\begin{array}{c}-0.15 \\
(0.37)\end{array}$ & $\begin{array}{c}0.23^{* *} \\
(0.087)\end{array}$ \\
\hline (9) & $\mathrm{x}$ & $\mathrm{x}$ & $\mathrm{x}$ & $\mathrm{x}$ & $\mathrm{x}$ & $X$ & $\begin{array}{l}-0.26 \\
(0.55)\end{array}$ & $\begin{array}{c}-0.19 \\
(0.50)\end{array}$ & $\begin{array}{c}0.062^{*} \\
(0.034)\end{array}$ & $\begin{array}{c}0.81 \\
(1.59)\end{array}$ & $\begin{array}{c}0.25 \\
(0.34)\end{array}$ & $\begin{array}{c}0.17 \\
(0.12)\end{array}$ \\
\hline
\end{tabular}

Notes: The dependent variable is the log of GDP. Robust standard errors are in parentheses. The model numbers (1) through (9) correspond to those in Table 4.A.B. ${ }^{*},{ }^{* *},{ }^{* * *}$ indicate that the coefficients are significant at the 10 , 5 , and 1 per cent level respectively.

\section{References}

Acemoglu, D., Johnson, S., and Robinson, J.(2001), “An African Success Story: Botswana", MIT Department of Economics Working Paper, 01-37.

Arellano, M. and Bond, S.(1991), "Some Tests of Specification for Panel Data: Monte Carlo Evidence and an Application to Employment Equations", Review of Economic Studies, 58(2), pp. 277-97.

Arellano, M. and Bover, O.(1995), "Another Look at the Instrumental Variable Estimation of Error-Components Models", Journal of Econometrics, 68, pp. 29-51.

Balasubramanyam, V. N., Salisu, M. and Sapsford, D.(1996), "Foreign Direct Investment and Growth in EP and IS Countries", the Economic Journal, 106(1), pp. 92-105.

Baldwin, R.(2003), “Openness and Growth: What's the Empirical Relationship?", NBER Working Paper, 9578.

Barro, R.(1991), "Economic Growth in a Cross Section of Countries", Quarterly Journal of Economics, 106(2), pp. 407-443.

Barro, R., and Lee, J-W.(2000), "International Data on Educational Attainment: Updates and Implications", Working Paper, No.42, Center for International Development (CID).

Benhabib, J. and Spiegel, M.(1994), "The Role of Human Capital in Economic Development: Evidence from Aggregate Cross-Country Data", Journal of Monetary Economics, 34, pp. 143-173.

Blonigen, B. A., and Wang, M.(2005), "Inappropriate Pooling of Wealthy and Poor Countries in Empirical FDI Studies", Does Foreign Direct Investment Promote 
Development? pp. 221-243, Institute for International Economics: Center for Global Development.

Blundell, R. and Bond, S.(1998), "Initial Conditions and Moment Restrictions in Dynamic Panel Data Models", Journal of Econometrics, 87, pp. 115-143.

Borensztein, E., de Gregorio J. and Lee. J.(1998), "How Does Foreign Direct Investment Affect Economic Growth?”, Journal of International Economics, 45, pp. 115-35.

Carkovic, M. and Levine, R.(2005), "Does Foreign Direct Investment Accelerate Economic Growth? Does Foreign Direct Investment Promote Development?", 195220, Institute for International Economics: Center for Global Development.

Caselli, F., Esquivel, G. and Lefort, F.(1996), "Reopening the Convergence Debate: a New Look at Cross-Country Growth Empirics", Journal of Economic Growth, I, pp. 363389.

de Mello, L. R., Jr.(1997), "Foreign Direct Investment in Developing Countries and Growth: a Selective Survey", Journal of Development Studies, 34, pp. 1-34.

Dollar, D. and Kraay A.(2004), "Trade, Growth, and Poverty", Economic Journal, 114, F22-F49.

Dollar, D.(1992), "Outward-Oriented Developing Economies Really Do Grow More Rapidly: Evidence from 95 LDCs, 1976-85", Economic Development and Cultural Change, 40, pp. 523-544.

Felbermayr, G.(2005), "Dynamic Panel Data Evidence on the Trade-Income Relation", Review of World Economics, 141(4), pp. 583-611.

Fu, X. and Balasubramanyam, V. N.(2005), "Exports, Foreign Direct Investment and Employment: the Case of China", The World Economy, 28(4), pp. 607-625.

Hanson, G. H., Mataloni Jr. R. J., and Slaughter, M.(2005), "Vertical Production Networks in Multinational Firms", Review of Economics and Statistics, November 87, pp. 664678.

Krueger, A. B., Lindahl, M.(2001), "Education for Growth: Why and for Whom?", Journal of Economic Literature, 39, pp. 1101-1136.

Levine, R. and Renelt, D.(1992), "A Sensitivity Analysis of Cross-Country Growth Regressions", American Economic Review, 82(4), pp. 942-963.

Lipsey, R. E.(2004), "Home and Host Country Effects of Foreign Direct Investment", in Baldwin R. E. and Winters L. A. (Eds.), Challenges to Globalization: Analyzing the Economics, pp. 333-379, Chicago and London: University of Chicago Press.

Mehlum, H., Moene, K., and Torvik, R.(2006), "Cursed by Resources or Institutions?", the World Economy, 29(8), pp. 1117-1131.

Moran, T. H.(2005), "How Does FDI Affect Host Country Development? Using Industry Case Studies to Make Reliable Generalizations", Does Foreign Direct Investment Promote Development? pp. 281-313, Institute for International Economics: Center for Global Development.

Olsson, O.(2006), "Diamonds Are a Rebel's Best Friend”, The World Economy, 29(8), pp. $1133-1150$.

Pritchett, L.(2001), "Where Has All the Education Gone?", The World Bank Economic 
Review, 15(3), pp. 367-391.

Rodriguez, F. and Rodrik, D.(2001), "Trade Policy and Economic Growth: a Skeptic's Guide to the Cross-National Evidence", Macroeconomic Annual 2000, 261-324, Cambridge, MA: MIT Press for NBER.

Roodman, D.(2006), "How to Do xtabond2: an Introduction to "Difference" and "System" GMM in Stata", Center for Global Development Working Paper, 103.

Sachs, J. D. and Warner, A.(1995), "Economic Reform and the Process of Global Integration", Brookings Papers on Economic Activity, No.1.

Slaughter, M.(2002), "Does Inward Foreign Direct Investment Contribute to Skill Upgrading in Developing Countries?", CEPA Working Paper, 2002-08, New School University.

UNCTAD(2006), World Investment Report 2006: FDI from Developing and Transition Economies: Implications for Development.

Wang, M.(2003), Essays on Foreign Direct Investment, Ph.D. Dissertation, University of Oregon.

Winters, L. A.(2004), "Trade Liberalization and Economic Performance: an Overview", Economic Journal, 114 (February), F4-F21.

Wacziarg, R.(2001), "Measuring the Dynamic Gains from Trade", World Bank Economic Review, 15(3), pp. 393-429.

World Bank, World Development Indicators, Washington, D.C. 